\title{
PSYCHOLOGICAL REACTIONS TO THE CONSUMPTION EXPERIENCE OF ONLINE SHOPPERS WITH E-COMMERCE
}

\section{Dr. M. Shamsath Begam}

\begin{abstract}
Due to the recognition of information technology and internet technology and in-depth applications, e-commerce is proceeding at an exceptional rate. Currently, the relatively rapid development of e-commerce activities is online sales, online promotions and online services. Globalization of e-commerce as a business development has provided many opportunities. To satisfy the e-commerce environment is related to consumer, consumer loyalty, and thus ebusiness performance. Therefore, in order to gain more profits from many companies, it is necessary to carefully investigate the behavior of consumers in the electronic business environment in order to understand the factors affecting the consumption environment as the e-commerce rapidly increases. Therefore, through the basis of network marketing for the composition characteristics of the index system to evaluate customer satisfaction, then countermeasures, and theoretical effective and rational marketing strategies based on customer satisfaction for development, e-commerce improves business performance and improves Let's promote healthy development. At present, the network of scholars at home and abroad on consumer psychology, motivation and behavior has more exposure, but there are not many ways to improve customer satisfaction surveys for e-commerce environments and e-commerce. This article analyses the impact of environmental factors on customer satisfaction in e-commerce networks.
\end{abstract}

Keywords: e-commerce, consumer loyalty, e-business performance, consumer psychology, customer satisfaction

\section{INTRODUCTION}

Recently, the internet population has exploded. World Wide Web (WWW) users have grown rapidly and have spread across all sectors. Internet use is no longer limited to computer users who use the Internet for fun or curiosity. It opened up great business opportunities for users. 
Of course, customer satisfaction has become an important issue in the success of each business system, whether traditional or virtual shopping. According to the information we have obtained, the networks driven by waves, industrial restructuring and modernization around the world are accelerating. Internet exhibition information, online transactions, contract signing, electronic transaction and e-commerce time constraints through series calculation, information transfer and processing means for logistical and orderly outages have been significantly improved, significantly reducing transaction costs, making existing production methods not only has it changed significantly, it has had a wide range of impacts as well as managing existing service and consumption patterns. With the improvement of living standards and the acceleration of the rhythm of life, consumer's buying behavior has changed significantly.

\section{LITERATURE REVIEW}

As e-commerce grows and makes more use of the properties of the Internet, it seems to have a significant impact on the national economy and industrial structure. E-commerce has taken on two important roles. Firstly, as a more effective and efficient means of communication and information gathering, and secondly, external vendors competing for performance as potential mechanisms that can replace many of the economic activities performed within the company. As these outsourcing opportunities increase, the company will take advantage of ecommerce by separating as many links as possible in the production chain to find the most efficient and affordable suppliers in the electronic market. Given that the Internet is expanding globally, this new e-market has quickly become a product of globalisation, leading the Internet and e-commerce to continue the global integration process. The most basic form of e-commerce is transactions over the Internet. In most cases, this involves the transfer of goods, services or information.

The definition of customer satisfaction has been widely discussed as organisations attempt to measure customer satisfaction. Customer satisfaction can be felt in a variety of situations and is related to products and services. It's a very personal assessment that is highly influenced by customer expectations. Satisfaction is based on the experience and personal results that the customer has come into contact with the organization. Some researchers define satisfied customers in the private sector as receiving added value for public services, and customer satisfaction is the overall result of perceptions, evaluations and psychological responses to consumption experiences. 
According to Kottler (2000, P.36), satisfaction refers to a person's joy or disappointment as a result of comparing a product's performance or perceived results with expectations.

The first concept of the study of satisfaction generally defined satisfaction as a choice and evaluation judgment regarding a particular purchasing decision (Churchill and Surprenant, 1992; Oliver, 1980). Yang Fang (2004) believes that even if an online customer chooses a pure Internet provider that provides basic customer service, they still demand many of the services offered through existing channels.

Expectations seem less important as a comparison standard for e-commerce (Zeithaml et al., 2000), but customers appear to be using experience-based standards (Cadotte et al., 1987) and services. Since there is a strong relationship between product quality, customer satisfaction and profitability, securing and achieving customer satisfaction today is the company's primary goal.

This survey provides useful data showing clear steps for improvement. Customer satisfaction is a very personal rating that is highly influenced by individual expectations. Some definitions are based on the observation that customer satisfaction or dissatisfaction is the result of confirming or non-confirming individual expectations of a service or product. Focus on more relevant targets that are more closely related to customer stakes. It encourages the company to determine how the customer is responsible, without asking if the customer is satisfied.

\section{RESEARCH SCOPE}

Tamil Nadu is an India's most populated area. About 82.4 million people live in this state. Therefore, this is a good opportunity for the corporate sector. From large enterprises to small industries, companies are connected to provide products and services to a new group of people around the world. From simple shopping sites to advanced database-based solutions, data capture and credit card verification, there are many ways to bring the products and services online. Complete and profitable e-commerce solutions vary from company to company. It is clear that online sales will increase. This improves the availability of online shopping. Tamil Nadu's retailers shouldn't be left behind, as online shopping is intensifying, and competition is getting more intense. As the importance of the Internet continues to grow in Tamil Nadu, the importance of the online retail industry is growing. The growth of the Internet and e-commerce has changed the way products and services are marketed and sold. 
The development of electronic information resources and the development of digital product and information service providers create many new challenges. The Internet is changing the way we do business with consumers who expect more and more services, save time and want more convenience. In addition, the quality of electronic services is an essential strategy for success, according to the results of previous literature, which is more important than the low price of online business. One of the main functions of the Internet as a communication channel is to manage the quality of service that is important to customer satisfaction. It is also clear from the literature that there is a relationship between electronic trust, satisfaction and quality. For this reason, a model with 4 website quality factors was selected for testing to determine the impact of website quality factors on customer satisfaction based on detailed document analysis. Trust in traditional business objects is a real store, trust in e-commerce by indirect objects on a website, direct objects as one of the online stores. The emergence of ecommerce has caused serious problems with the exchange of goods and capital, the anonymity and asymmetry of traders, and other news, and the factors affecting customer satisfaction are: It is quite different.

\section{IMPORTANCE OF RESEARCH}

The development of e-commerce activities, the traditional way of commerce, has brought about fundamental changes in consumer status, and not only over the network, but also to the active state of the former passive consumer to find what is needed. It provides quick information about the product, but it can easily transform the seller. Therefore, in internet time, it is much more important to satisfy customers and retain customers for e-business compared to traditional business. In addition, current consumer satisfaction and confidence in online shopping are not high.

\section{PURPOSE OF RESEARCH}

This perspective aims to study the psychological reactions to the consumption experience of online shoppers with E-commerce based on the Tamil Nadu. The main goal was to apply the idea of two factor theory to the empirical context are designing the following research questions to better serve the purpose of this research.

What is the satisfaction level of consumers when shopping online? How important are these marks to customer satisfaction?

How can e-commerce in online shopping are improved? What factors should be involved as a network seller? 


\section{Dr. M. Shamsath Begam / Page 214-225}

\section{RESEARCH DESIGN}

Research methods are defined as a collection of reliable, well-ordered rules, tools and tools for studying reality, revealing passivity and obtaining solutions.

Based on the customer satisfaction model, this study utilized the theory of two factors as a guide, while the hygiene coefficient is considered the basis of customer satisfaction, while the motivation coefficient is the key to improving customer satisfaction. At the same time, they need to unify and look as a whole to satisfy their customers. To achieve this goal, we first define the influencing factors of customer satisfaction, then clarify and differentiate the benefits.

\subsection{DATA COLLECTION}

There are many ways to measure information to answer research questions. One way is to collect information from different sources and include all kinds of necessary information. Several actions were taken to select an appropriate and accurate method of information, including analytical and reporting resources, available resources, evaluator reliability and competency. The sources of data collection proposed in this study are databases and books from research libraries on university libraries, the Internet, corporate websites, and facilities and databases, and sampling data is obtained through online surveys. This includes the process of driving customers to e-commerce and how to achieve customer satisfaction.

\subsection{QUESTIONNAIRE DESIGN AND DISTRIBUTION}

The preliminary design of the questionnaire is based on documentary studies and individual interviews combined with the specific circumstances of this formed study. Read many important documents related to Tamil Nadu online shopping and sort the repetition rate of the index. Online store users have individual interviews, and suggested metrics were selected for each respondent.

\subsection{DATA ANALYSIS AND RESULTS DISCUSSION}

In this survey, 230 questionnaires were distributed and 194 were collected from the online shoppers. The analysis is as follows.

Table 1: Demographic Profile of the Respondent

\begin{tabular}{|l|l|c|c|}
\hline \multicolumn{2}{|c|}{ Demographic Variables } & No.of Respondents & Percentage \\
\hline \multirow{2}{*}{ Gender } & Men & 129 & 65.82 \\
\cline { 2 - 4 } & Women & 67 & 34.18 \\
\hline Marital Status & Married & 87 & 44.39 \\
\hline
\end{tabular}


Towards Excellence: An Indexed, Refereed \& Peer Reviewed Journal of Higher Education /

Dr. M. Shamsath Begam / Page 214-225

\begin{tabular}{|c|c|c|c|}
\hline & Unmarried & 109 & 55.61 \\
\hline \multirow{4}{*}{ Age (in years) } & $20-30$ & 76 & 38.78 \\
\hline & $30-40$ & 58 & 29.59 \\
\hline & $40-50$ & 42 & 21.42 \\
\hline & Above 50 & 20 & 10.2 \\
\hline \multirow{4}{*}{$\begin{array}{l}\text { Educational } \\
\text { Qualification }\end{array}$} & Up to H.S.C & 21 & 10.71 \\
\hline & Diploma & 32 & 16.33 \\
\hline & Graduate & 97 & 49.48 \\
\hline & Post - Graduate & 46 & 23.47 \\
\hline \multirow{3}{*}{$\begin{array}{l}\text { Monthly Income } \\
\text { (in Rupees) }\end{array}$} & $10000-15000$ & 51 & 26.02 \\
\hline & $15000-20000$ & 63 & 32.14 \\
\hline & Above 20000 & 82 & 41.84 \\
\hline \multirow[t]{3}{*}{ Online Purchasing } & $1-5$ times & 23 & 11.73 \\
\hline & $5-10$ times & 94 & 47.96 \\
\hline & Over 10 times & 79 & 40.31 \\
\hline
\end{tabular}

Studies have shown that men are 65.82 per cent, unmarried are 55.61 per cent and 49.48 per cent. According to the results of the survey, the majority of the online shopping population is graduated unmarried men.

\subsection{MEASURE OF CUSTOMER'S SATISFACTION}

Exponential calculation can be done in direct calculation method, percentage method and weighted average method. In this study, the weighted average method is used to calculate the index that measures the level of the customer satisfaction index and the importance of the indicators of the satisfaction factor.

Table 2: Index of the Consumer Satisfaction

\begin{tabular}{|l|c|c|c|c|c|c|c|c|c|c|c|}
\hline $\begin{array}{c}\text { Assessment } \\
\text { Varible }\end{array}$ & \multicolumn{2}{|c|}{ Disappointed } & \multicolumn{2}{|c|}{$\begin{array}{c}\text { Modest } \\
\text { Dissatisfied }\end{array}$} & \multicolumn{2}{|c|}{ Neutral } & \multicolumn{2}{|c|}{ Fulfilled } & \multicolumn{2}{|c|}{$\begin{array}{c}\text { Incredibly } \\
\text { Satisfied }\end{array}$} & $\begin{array}{c}\text { Mean } \\
\text { Score }\end{array}$ \\
\cline { 2 - 12 } & NR & F & NR & F & NR & F & NR & F & NR & F & \\
\hline $\begin{array}{l}\text { Web } \\
\text { process }\end{array}$ & 12 & 6.12 & 14 & 7.14 & 85 & 43.37 & 57 & 29.08 & 28 & 14.29 & 2.63 \\
\hline $\begin{array}{l}\text { Operating } \\
\text { speed }\end{array}$ & 8 & 4.08 & 19 & 9.69 & 79 & 40.31 & 76 & 38.78 & 14 & 7.14 & 2.89 \\
\hline Transaction & 9 & 4.59 & 11 & 5.61 & 72 & 36.73 & 73 & 37.24 & 31 & 15.82 & 2.52 \\
\hline
\end{tabular}


Towards Excellence: An Indexed, Refereed \& Peer Reviewed Journal of Higher Education /

Dr. M. Shamsath Begam / Page 214-225

\begin{tabular}{|l|c|c|c|c|c|c|c|c|c|c|c|}
\hline security & & & & & & & & & & & \\
\hline Confidential & 13 & 6.63 & 9 & 4.59 & 76 & 38.78 & 83 & 42.35 & 15 & 7.65 & 2.96 \\
\hline $\begin{array}{l}\text { Response to } \\
\text { demand }\end{array}$ & 17 & 8.67 & 34 & 17.35 & 69 & 35.20 & 49 & 25.00 & 27 & 13.78 & 2.25 \\
\hline $\begin{array}{l}\text { Product } \\
\text { description }\end{array}$ & 21 & 10.71 & 18 & 9.18 & 54 & 27.55 & 79 & 40.31 & 24 & 12.24 & 2.41 \\
\hline $\begin{array}{l}\text { Product } \\
\text { quality }\end{array}$ & 19 & 9.69 & 27 & 13.78 & 46 & 23.47 & 81 & 41.33 & 23 & 11.73 & 2.38 \\
\hline $\begin{array}{l}\text { Product } \\
\text { price }\end{array}$ & 24 & 12.24 & 19 & 9.69 & 42 & 21.43 & 93 & 47.45 & 18 & 9.18 & 2.70 \\
\hline $\begin{array}{l}\text { Convenient } \\
\text { shopping }\end{array}$ & 29 & 14.80 & 23 & 11.73 & 54 & 27.55 & 76 & 38.78 & 14 & 7.14 & 2.52 \\
\hline $\begin{array}{l}\text { Speed of } \\
\text { delivery }\end{array}$ & 12 & 6.12 & 31 & 15.82 & 65 & 33.16 & 59 & 30.10 & 29 & 14.80 & 2.23 \\
\hline
\end{tabular}

NR - Number of Respondent F - Frequency

Indicators include a number of factors, but the impact on customer satisfaction is different because different indicators of customer meaning and importance are different. Therefore, in addition to calculating the Customer Satisfaction Index, it is necessary to distinguish the relative importance of each indicator, which is usually represented by 5 components.

Table 3: Weight of the Consumer Satisfaction Factor

\begin{tabular}{|l|c|c|c|c|c|c|c|}
\hline \multicolumn{1}{|c|}{ Variable } & $\begin{array}{c}1 \text { point } \\
\text { Not } \\
\text { important }\end{array}$ & $\begin{array}{c}2 \text { points } \\
\text { Less } \\
\text { important }\end{array}$ & $\begin{array}{c}3 \text { points } \\
\text { Neutral }\end{array}$ & $\begin{array}{c}4 \text { points } \\
\text { Important }\end{array}$ & $\begin{array}{c}5 \text { points } \\
\text { Very } \\
\text { important }\end{array}$ & Total & $\begin{array}{c}\text { Weight } \\
\text { score }\end{array}$ \\
\hline $\begin{array}{l}\text { Web } \\
\text { process }\end{array}$ & 13 & 25 & 64 & 75 & 19 & 650 & 2.51 \\
\hline $\begin{array}{l}\text { Operating } \\
\text { speed }\end{array}$ & 9 & 34 & 59 & 83 & 11 & 641 & 2.75 \\
\hline $\begin{array}{l}\text { Transaction } \\
\text { security }\end{array}$ & 15 & 31 & 56 & 85 & 9 & 630 & 2.77 \\
\hline Confidential & 14 & 29 & 57 & 89 & 7 & 634 & 2.90 \\
\hline Response to & 9 & 36 & 60 & 79 & 12 & 637 & 2.68 \\
\hline
\end{tabular}


Dr. M. Shamsath Begam / Page 214-225

\begin{tabular}{|l|c|c|c|c|c|c|c|}
\hline demand & 18 & 37 & 52 & 81 & 8 & 612 & 2.70 \\
\hline $\begin{array}{l}\text { Product } \\
\text { description }\end{array}$ & 11 & 31 & 61 & 76 & 16 & 640 & 2.55 \\
\hline $\begin{array}{l}\text { Product } \\
\text { quality }\end{array}$ & 17 & 30 & 63 & 65 & 21 & 631 & 2.34 \\
\hline $\begin{array}{l}\text { Product } \\
\text { price }\end{array}$ & 8 & 27 & 49 & 88 & 24 & 681 & 2.54 \\
\hline $\begin{array}{l}\text { Convenient } \\
\text { shopping }\end{array}$ & 16 & 32 & 58 & 64 & 26 & 640 & 2.21 \\
\hline $\begin{array}{l}\text { Speed of } \\
\text { delivery }\end{array}$ & & & & & & & \\
\hline
\end{tabular}

Improvements are urgent to analyze the hygiene factors in the table above. It is the most urgent business investment in resources for improvement. If these factors are very good, they can turn into a competitive advantage. Depending on the score of each factor, the factor can be improved from low to high. However, careful analysis reveals that the main task of improvement measures should be the biggest difference between realistic customer expectations and online shopping.

\section{RESULTS AND DISCUSSION}

Business is an important part of our economy and life. Today, the reliance on the Internet for all kinds of businesses is increasing significantly. E-commerce is one of the key elements of business success. As mentioned earlier, our goal is to satisfy online customers and improve online shopping in e-commerce. Open a new window for business and dramatically reduce the distance. Many other potential opportunities for small entrepreneurs have been created. Today, thanks to Internet facilities, the quality of customer service has improved. Each company wants to provide better service to resist in difficult environments. 24-hour automated online customer support is ready to provide you with the right support. Online forums, online chat, and instant messaging services are all the advantages of this technology. This measure takes into account the country's Internet infrastructure, business environment, adoption of e-commerce by consumers and businesses, cultural acceptance and favorable legal environments. The Internet is one of the cheapest ways to communicate with customers and customers who do business online. E-commerce web development companies make it easy to buy and sell products and services. 


\section{Dr. M. Shamsath Begam / Page 214-225}

\subsection{LIMITATION}

The core network, which is the collection of most $\mathrm{C} 2 \mathrm{C}$ e-commerce objects, is not involved in B2B stores. Also, the above suggestions are broad and speak for different business segments in terms of different types of networks, but their applicability is not the same. According to certain types of business, future research on specific industries suggests that online marketers will provide detailed and detailed recommendations to provide more specific, useful and practical advice. These above problems may distort the evaluation results to some extent.

\subsection{SUGGESTIONS}

Our results indicate that reliability is the most important quality indicator. Also, since customer service is the only factor that directly affects satisfaction, raising your satisfaction immediately is a key strategy. The results presented in this study not only help companies find their location compared to competitors, identify weaknesses, and determine which features of the website will improve performance, but also information and this service is used by all users The degree to which you need features to provide an effective and efficient website to understand and meet the needs of a diverse user population.

For online merchants:

- Accelerate network reaction speed

- $\quad$ Secure payment system construction and transaction security

- Improve communication with consumers

- Logistics and distribution

- $\quad$ Reduced possibility of return

\section{CONCLUSION}

This study is based on two questions. One is online customer satisfaction and the other is ecommerce improvement. It's difficult to browse the websites of some companies, and the technology used is unreliable, so many consumers take a long time to complete online transactions. Individuals hesitate to purchase new products using unknown procedures on the Internet. First of all, customers need to trust the company. Second, customers must trust products that are better than products from existing sources. Third, customers need to be comfortable and safe with the purchasing process and technology. The company provides many resources and expertise to understand and respond to customer needs. Companies need to design user-friendly websites through procedures that customers can trust. In traditional marketing mode, motivation and hygiene factors are defined by business mode. It is difficult 
to use real elements and protection and motivation elements. According to the two-step theory, in order to improve customer satisfaction, the company must define products and two rational elements: motivational products and rational definitions of hygiene factors. The most basic new and long-term interaction is your starting point. In this study, the process of customer satisfaction and the customer satisfaction system reflect the voice of customers based on the formation of consumer opinions. In addition, as part of the customer satisfaction survey, respondents were asked to assess the importance of various indicators, which can analyze network activity to identify the most important and most important factors for customers. Continued analysis of customer satisfaction surveys with technological improvements, improved management, and changes in customer needs and preferences can lead to hygienic motivational factors in dynamic changes. On the other hand, motivation motivates new customer needs, bringing new benefits to business growth. Customer satisfaction surveys should be objective and regular, and previous survey results should be compared. Satisfaction with consumer products and services for the business and the business itself is constantly evolving. Therefore, companies need to pay attention to continuously motivating new consumers to stimulate their purchasing needs. 


\section{References}

Arivazhagan, R. and Geetha, P. (2011), A Study on Consumer Awareness and Satisfaction towards Orange Flavored Soft Drinks in Tamil Nadu, Indian Journal of Commerce \& Management Studies.

Bergstein, H. (2006), The impact of market price volatility on consumer satisfaction with lowest-price refunds, Journal of Services Marketing, pp.20-23.

Cadotte, E. R., Woodruff, R.B., Jenkins, R.L., (1987). "Expectations and norms in models of consumer satisfaction". Journal of Marketing Research. 24(3) 305-314

C.Ranganathan and Shobha Ganapathy (2002). Key Dimensions of business-to ConsumerWeb Sites. Information Management, (39): P.457- 465

Daniel Gorsch. Internet Limitations, Product Types, and the Future of Electronic Retailing.[J]. 1St Nordic.

David M. Szymanski, Richard T. Hise (2000). E-satisfaction An Initial Examination.Journal of Retailing. 76 (3), [309-322]

Huber, F. and Herrmann, A. (2001), Achieving brand and dealer loyalty: the case of automotive industry, International Review of Retail, Distribution \& Consumer Research, Vol. 11 No. 2, pp.28-34.

Jagdish N. Sheth, Banwari Mittal (2004). Customer Behavior: A Managerial Perspective(2nd Edition) [M], China Machine press.

Jan Chaston (2001). E-marketing Strategy [M], Social science documentation Publishing House.

Kenneth L. Kraemer, Jennifer Gibbs, Jason Dedrick (2002). Impacts of Globalization on E-Commerce Adoption and Firm Performance: A Cross-Country Investigation.

Oliver, R.L., (1980) "A cognitive model of the antecedents and consequences of satisfaction decisions" Journal of Marketing Research, Vol. XVII, November.

Oliver, R.L., (1993), "cognitive, affective and attribute bases of the satisfaction response", Journal of consumer research, Vol.20, No. 3, pp.418-30.

Parasuraman, A., Zeithaml, V.A. and Berry, L.L. (1988), A multiple-item scale for measuring consumer perceptions of service quality, Journal of Retailing, Vol. 64 No. 1.

Paul May (2000). The Business of E-commerce [M] J. Cambridge: Cambridge University Press. 
Pavithra, K., Sangita D. and Subramani, A. K. (2015), A study on customer satisfaction towards coco-cola, International Journal of Multidisciplinary Research, Vol.5, Issue: 6 .

Raphl Amit, Christoph Zott (2001). Value Creation in E-business [J]. Strategic Management Journal (22): P.493-520.

Thangam, M. and Karthikeyan (2016), An empirical study on consumers perception towards soft drinks, Journal of marketing, financial services and management research, Vol. 5, Iss. 4, pp.38-44.

Zeithaml, V.A., Parasuraman, A.,Malhotra, A. (2000): A Conceptual Framework for Understanding e-Service Quality: Implications for Future Research and Managerial Practice: Working paper, Cambridge MA, Marketing Science Institute, Report Number 00-115.

Dr. M. Shamsath Begam

Assistant professor

\section{PG \& Research Department of Commerce}

Khadir Mohideen College

(Affiliated to Bharathidasan University, Tamil Nadu), Adirampattinam

E-mail: syedsamsat@gmail.com

Mobile Number: 8778493321 